\title{
Effect of Fenfluramine on Human Growth Hormone Release
}

\author{
W. R. SULAIMAN, R. H. JOHNSON
}

British Medical fournal, 1973, 2, 329-332

\section{Summary}

In order to investigate the effect of fenfluramine on hormonal and metabolic changes with exercise, five normal volunteers have been studied during and after 20 minutes of steady exercise on a bicycle ergometer after injection of fenfluramine ( $20 \mathrm{mg}$ intravenously). Fenfluramine abolished the rise of plasma human growth hormone (HGH) which occurred in control investigations. Fenfluramine also affected plasma insulin, blood glucose, and ketone body levels.

The acute effect of fenfluramine on the release of growth hormone was examined further by studying its effect in patients with acromegaly. A marked depression of growth hormone occurred both at rest and with exercise. These observations indicate that fenfluramine has a direct effect on pathways controlling growth hormone release. We also suggest that this action may have practical use in the medical treatment of acromegaly.

\section{Introduction}

Fenfluramine (Ponderax), a derivative of amphetamine, has been reported to cause weight loss in man (Duncan et al., 1965; Traherne, 1965; Munro et al., 1966) and animals (Alphin et al., 1964; Le Douarec and Schmitt, 1964) and is used in the management of obesity. Its mode of action is, however, still uncertain and has been attributed to either a direct metabolic effect of fenfluramine on fat and carbohydrate metabolism (Butterfield and Whichelow, 1968; Dannenburg and Kardian, 1969; Pawan, 1969) or a depressant action on centres in the central nervous system regulating appetite and food intake (Foxwell et al., 1968). Experimental observations on animals have indicated the hypothalamus as a possible site for the action of the drug (Anand, 1971; Anand and Blundell, 1971).

The hypothalamus influences the secretion of hormones of the anterior pituitary, including growth hormone, via intermediary neurohormones (McCann, 1970). It is therefore possible that alteration of release of growth hormone may occur with drugs affecting the hypothalamus. Should such changes occur they would provide evidence for the hypothalamus or its connexions being a major site of action of the drug. Preliminary observations in normal human subjects showed that fenfluramine caused a depression in the level of plasma human growth hormone $(\mathrm{HGH})$ when subjects were at rest. Resting levels of $\mathrm{HGH}$ are, however, low $(2-6 \mu \mathrm{U} / \mathrm{ml})$ and, as exercise is a situation known to stimulate the release of $\mathrm{HGH}$ (Hunter and Greenwood, 1964; Hunter et al., 1965), we have studied the effect of fenfluramine on the release of $\mathrm{HGH}$ and insulin in relation to the metabolic response to exercise in normal volunteers.

Hypothalamic dysfunction may result in acromegaly in some patients. In acromegaly the hypersecretion of $\mathrm{HGH}$ is not

\footnotetext{
University Department of Neurology, Institute of Neurological Sciences, Southern General Hospital, Glasgow G51 4TF

always autonomous (Cryer and Daughaday, 1969; Lawrence et al., 1970) and the level may rise with an appropriate stimulus such as exercise (Johnson and Rennie, 1973). We have, therefore, studied a group of subjects with acromegaly when given fenfluramine. In one subject this was given before exercise. Our observations in normal subjects and patients with acromegaly indicate the suppressive action of fenfluramine on $\mathrm{HGH}$ release.

\section{Methods}

EFFECT OF ACUTE INJECTION OF FENFLURAMINE IN NORMAL VOLUNTEERS

Five healthy male volunteers (aged 24-38 years) with mean heights of $174 \mathrm{~cm}( \pm 3.2 \mathrm{~cm} \mathrm{S.E.} \mathrm{of} \mathrm{mean)} \mathrm{and} \mathrm{mean} \mathrm{weights}$ of $78.2 \mathrm{~kg}( \pm 3.8 \mathrm{~kg} \mathrm{S.E}$. of mean) exercised on a bicycle ergometer (Elema Schönander constant load ergometer, EM 369) on two separate occasions. On both occasions the subjects had fasted overnight, and exercised for $20 \mathrm{~min}$ at $600 \mathrm{kpond}$ $\mathrm{min}$, followed by a period of rest of $90 \mathrm{~min}$. Blood samples were taken from a catheter placed in an antecubital vein. Two resting samples were taken; further samples were also taken at 5-min intervals during exercise and then at 15, 30, 60, and 90 min after the exercise. On the second occasion intravenous fenfluramine $(20 \mathrm{mg})$ was given between the resting samples and exercise was started $5 \mathrm{~min}$ later. Heart rate was recorded with a continuous electrocardiogram.

EFFECT OF ACUTE INJECTION OF FENFLURAMINE ON PATIENTS WITH ACROMEGALY

At Rest.-Four patients with acromegaly (three women and one man, aged 44-72 years) with mean heights of $161 \mathrm{~cm}$ ( $\pm 3.6 \mathrm{~cm} \mathrm{S.E.} \mathrm{of} \mathrm{mean)} \mathrm{and} \mathrm{mean} \mathrm{weights} \mathrm{of} 72.3 \mathrm{~kg}$ ( $\pm 2.3 \mathrm{~kg}$ S.E. of mean) were studied. Their mean resting plasma $\mathrm{HGH}$ level after overnight fasting was $65.5 \mu \mathrm{U} / \mathrm{ml}( \pm 14.7 \mu \mathrm{U}$ S.E. of mean) and they were studied during investigation for acromegaly when no other therapy was being given. On the day of the investigation the patient had fasted overnight and rested in bed. A catheter was placed in an antecubital vein and intravenous fenfluramine (20 $\mathrm{mg}$ ) was administered. Venous samples were taken before the injection, and 5, 10,20,30,45, 60 , and 90 min later.

Exercise.-One male patient with acromegaly (aged 21 years), height $174 \mathrm{~cm}$ and weight $76 \mathrm{~kg}$, was studied on two separate occasions in the same manner as described above. His resting plasma $H G H$ level after overnight fasting was $76-74 \mu \mathrm{U} / \mathrm{ml}$ and no treatment or replacement therapy had been started.

\section{LABORATORY PROCEDURE}

In all investigations each blood sample was divided into two parts. Five $\mathrm{ml}$ was deproteinized by addition to $10^{\circ} \%$ perchloric acid. The remainder was heparinized and the plasma separated by centrifugation. All specimens were then stored in ice. The deproteinized samples were analysed for glucose (Bergmeyer and Bernt, 1963), lactate and pyruvate (Hohorst et al., 1959), acetoacetate and 3-hydroxybutyrate (Williamson et al., 1962). 
The plasma sample was analysed for free fatty acids by a colorimetric method after chloroform extraction (Itaya and $\mathrm{Ui}$, 1965), HGH was analysed by a radioimmunoassay using two antibodies (Morgan and Lazarow, 1963), and immunoreactive insulin by a charcoal immunoassay (Hunter, 1969; Hunter and Ganguli, 1971). The standards used were MRC Standard A for HGH and Wellcome MR71 for inmmuoreactive insulin.

\section{Results}

EFFECT OF ACUTE INJECTION OF FENFLURAMINE IN NORMAI VOLUNTEERS

Lactate and Pyruvate.-Resting blood lactate concentrations were similar on both occasions (fig. 1). During exercise the concentrations rose to a maximum at $15 \mathrm{~min}$ when there was no significant difference between the two occasions. The lactate concentrations returned to resting levels $60 \mathrm{~min}$ after exercise. The changes in pyruvate concentrations were similar.

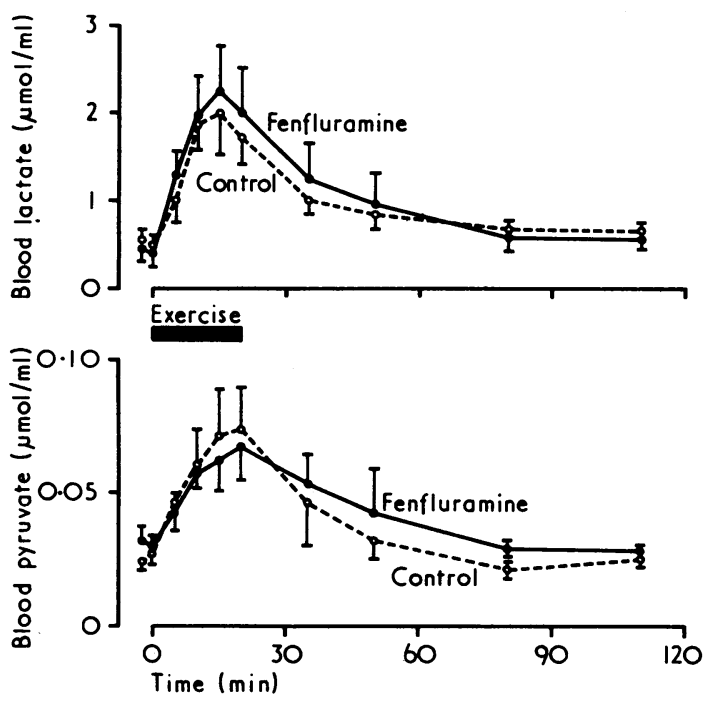

FIG. 1-Blood lactate and pyruvate levels $(\mu \mathrm{mol} / \mathrm{ml}$, means \pm S.E. of mean) in five subjects during and after two periods of $20 \mathrm{~min}$ exercise.

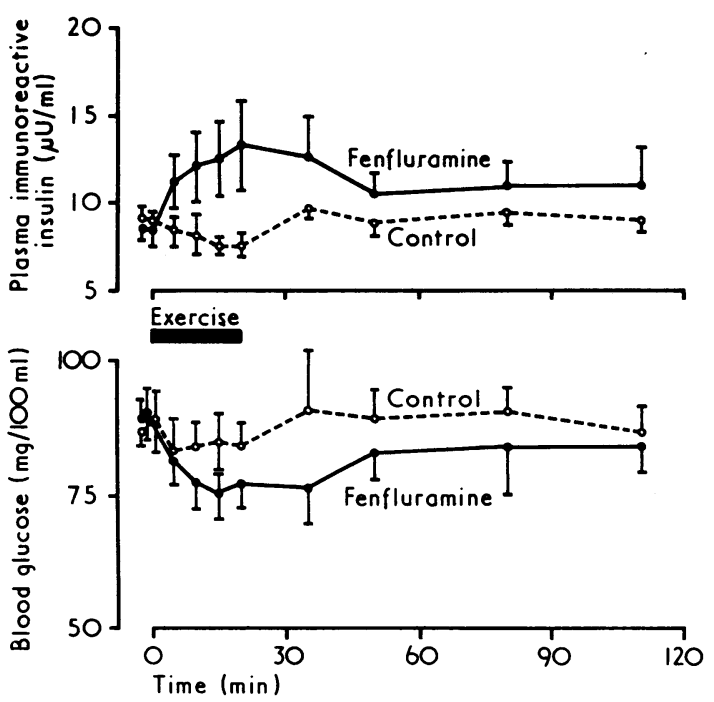

FIG. 2-Blood glucose $(\mathrm{mg} / 100 \mathrm{ml})$ and plasma immunoreactive insulin ( $\mu$ units $/ \mathrm{ml}$, means $\pm S$.E. of mean) in five subjects during and after two periods of $20 \mathrm{~min}$ exercise.
Glucose.-There was no difference in the resting concentrations of blood glucose on the two occasions (fig. 2). Exercise caused a fall in the concentrations at $5 \mathrm{~min}$ in the control investigation, but with fenfluramine the fall was more pronounced after 15 min of exercise when the concentration was significantly different from that of the control study $(P<0.05)$. Although the levels during recovery were not statistically different at any one time, on the control occasion the concentrations were consistently higher and returned to the resting level $15 \mathrm{~min}$ after exercise, whereas with fenfluramine the concentrations remained below the resting level throughout the remaining period of investigation.

Free Fatty Acids.-Resting plasma free fatty acid concentrations were not significantly different on the two occasions (fig. 3). Exercise caused similar rises in the concentrations of

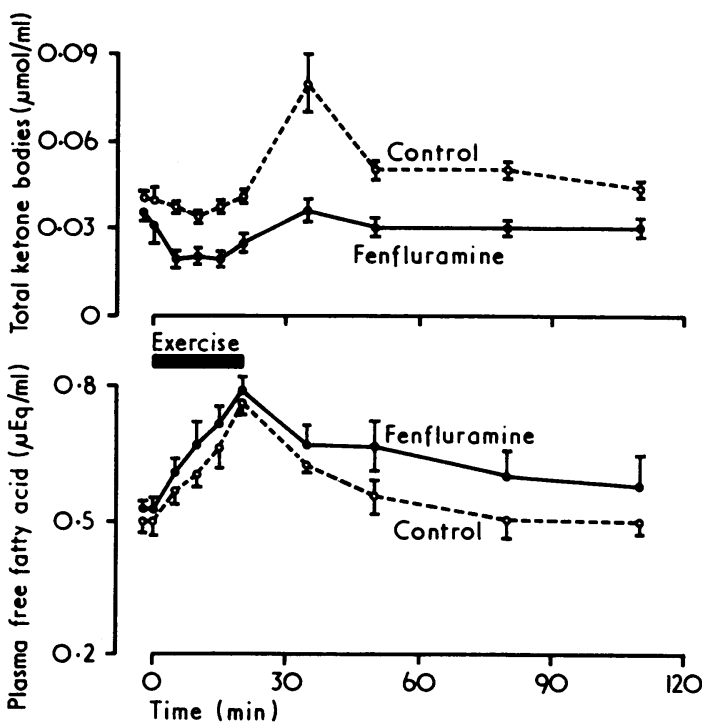

FIG. 3 Plasma-free fatty acids $(\mu \mathrm{Eq} / \mathrm{ml})$ and blood ketone $b$ udies ( $\mu \mathrm{mol} / \mathrm{ml}$, means \pm S.E. of mean) in five subjects during and after two periods of $20 \mathrm{~min}$ exercise.

free fatty acids with the maxima at the end of exercise. In the control investigation the concentrations returned to resting levels by the end of the investigation, whereas with fenfluramine they remained higher in the period after exercise although they were only significantly different from that of the control study at $30 \mathrm{~min}$ after exercise $(P<0.01)$.

Ketone Bodies.-Resting levels of total ketone bodies (acetoacetate plus 3-hydroxybutyrate) were not statistically different at rest (fig. 3). Exercise caused a small fall in concentrations on the control occasion, but with fenfluramine the fall was more pronounced $(P<0.01)$. The levels rose after the initial fall, both in the remaining part of exercise and for $15 \mathrm{~min}$ afterwards. The concentration was much greater at $15 \mathrm{~min}$ after exercise on the control occasion (100\% of resting) than with fenfluramine (14\% of resting). In the remaining period of the investigations the levels of ketone bodies slowly returned toward the resting value.

Plasma Immunoreactive Insulin.-Resting concentrations of plasma immunoreactive insulin were not statistically different on the two occasions (fig. 2). The concentration fell during exercise in the control study but rose with fenfluramine so that the difference in the concentrations between the two studies was significant throughout exercise $(P<0.05)$. In the control investigation the level returned to the resting value $15 \mathrm{~min}$ after exercise, but with fenfluramine the level returned more slowly and remained above the resting value. 
Plasma HGH.-At rest plasma HGH levels were similar on both occasions (fig. 4). During exercise there was a rise of $600 \%$ in the level toward the end of exercise on the control investigation. With fenfluramine, however, the rise was abolished.

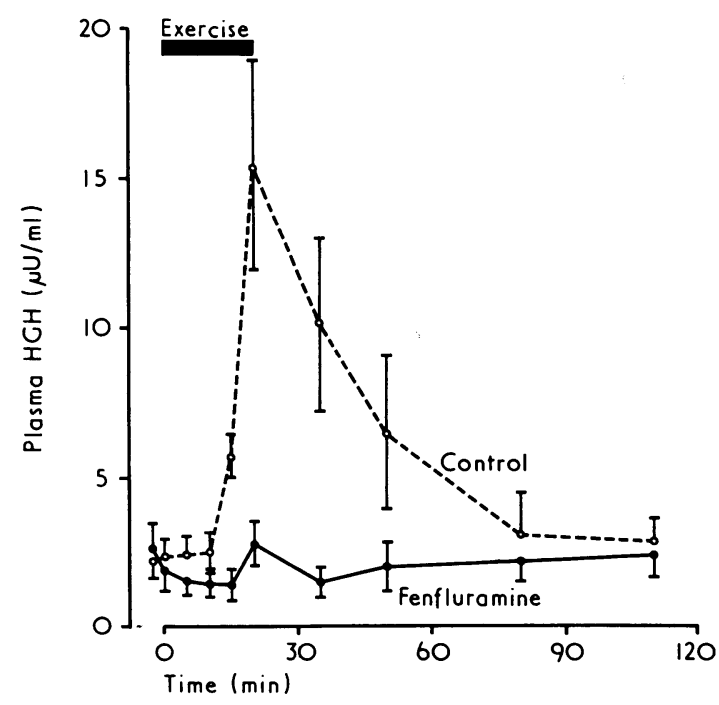

FIG. 4-Plasma HGH ( $\mu$ units $/ \mathrm{ml}$, means \pm S.E. of mean) in five subjects after two periods of $20 \mathrm{~min}$ exercise.

\section{EFFECT OF ACUTE INJECTION OF FENFLURAMINE ON PATIENTS WITH ACROMEGALY}

At Rest.-Fenfluramine caused the concentration of $\mathrm{HGH}$ to fall $23 \%, 20 \%$, and $28 \%$ at 20,30 , and $45 \mathrm{~min}$ after the injection respectively $(P<0.01)$ (fig. 5). The concentration returned to the original level $60 \mathrm{~min}$ after the injection.

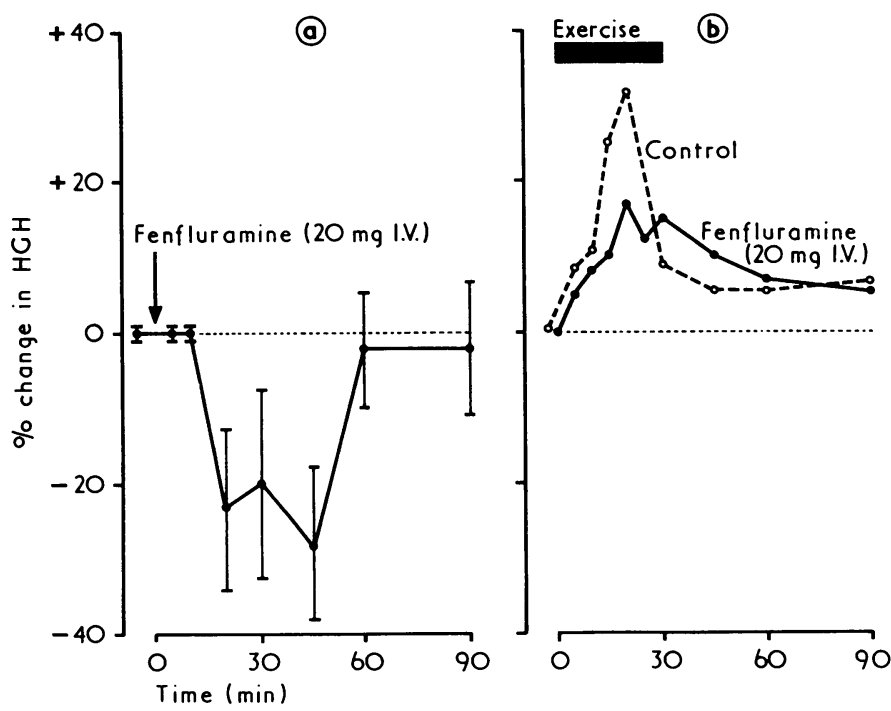

FIG. 5-Percentage change in plasma HGH (means \pm S.E. of mean) (a) in four acromegalic patients, after administration of fenfluramine at rest; and $(b)$ in an acromegalic patient during and after two periods of $30 \mathrm{~min}$ exercise.

Exercise.-On the control occasion exercise caused a progressive rise of $\mathrm{HGH}$ to a maximum of $32 \%$ above the resting level, whereas with fenfluramine the maximum was $17 \%$ above resting level (fig. 5).

\section{Discussion}

Exercise improves the peripheral uptake of glucose and its subsequent utilization. Increased glucose utilization also activates ketone body utilization in exercised muscle. Fenfluramine caused a greater fall in the concentrations of blood glucose and ketone bodies during exercise which may be attributed to increased peripheral uptake of glucose and its subsequent utilization. Increased glucose utilization by exercising muscles depends on the concentration of glycogen in the muscle. Although we have not studied muscle glycogen content, it is unlikely that decreased glycogen concentration in the muscle is the cause of the changes with fenfluramine because lactate and pyruvate concentrations were not altered. Fenfluramine, however, caused a rise in the concentration of plasma immunoreactive insulin during exercise instead of the usual fall. This increase could have contributed to differences in the level of blood glucose and ketone bodies. Despite the rise in the level of plasma immunoreactive insulin with fenfluramine the changes in free fatty acids with exercise were similar on both occasions. In the investigation with fenfluramine, however, the level of free fatty acids remained higher in the period after exercise. This might suggest that fat mobilization is not appreciably affected by fenfluramine, although the drug may reduce the rate of fat re-esterification. This supports the observation that in-vitro fenfluramine inhibits the metabolism of glucose to $\alpha$-glycerophosphate in adipose tissue and decreases fat synthesis (Wilson and Galton, 1971).

The secretion of HGH from the anterior pituitary is influenced by the hypothalamus through an intermediary neurohormone system which is probably controlled by adrenergic mechanisms (Fuxe and Hökfelt, 1969; Wurtman, 1970; Forhman, 1972). Some drugs, such as levodopa (Eddy et al., 1971; Kansal et al., 1972) and amphetamine (Besser et al., 1969), cause increased noradrenaline synthesis or turnover in brain and stimulate the release of $\mathrm{HGH}$ probably by stimulating hypothalamic activity. The cause of $\mathrm{HGH}$ release with exercise may therefore result from increased noradrenaline in the hypothalamus. Fenfluramine, however, depletes cerebral amines and decreases their concentration particularly in the hypothalamus (Costa et al., 1971; Ziance et al., 1972), and it may, therefore, interfere with HGH release by affecting the adrenergic activity of the hypothalamus. This mechanism may also explain the failure of the fall in glucose concentrations to stimulate $\mathrm{HGH}$ production in the investigation with fenfluramine, for hypoglycaemia also acts via its effect on adrenergic mechanisms in the brain (Blackard and Heidingsfelder, 1968).

In acromegaly, $\mathrm{HGH}$ release may still occur in response to some stimuli such as a glucose load and exercise (Cryer and Daughaday 1969; Lawrence et al., 1970; Johnson and Rennie, 1973), indicating that the hypothalamic-pituitary axis is still active in some patients. In our patients fenfluramine caused a depression in the concentration of $\mathrm{HGH}$ at rest and the rise in $\mathrm{HGH}$ during exercise in one patient was attenuated by the drug. These observations suggest that the drug may be of value in the medical management of acromegaly. There are, however, other situations particularly childhood and adolescence in which the drug might have undesirable effects on growth. Short periods of treatment in patients with obesity in these age groups therefore require further study in view of the observations now reported, from which we conclude that fenfluramine interferes with pathways in the central nervous system regulating the release of $\mathrm{HGH}$.

We thank the patients and subjects for their co-operation and Professor J. A. Simpson and Professor R. M. S. Smellie for encouragement. We also thank Dr. D. M. Park for his help with some investigations and Miss Christine McGregor for skilled technical help. Professor G. M. Wilson and Mr. R. A. Hide allowed us to study two of the patients. We are grateful to the Gulbenkian Foundation (for support for W. R. Sulaiman) and the Scottish Hospital Endowments Trust, the National Fund for Research into Crippling Diseases, and Servier Laboratories (who supplied fenfluramine) for support. 


\section{References}

Alphin, R. S., Funderburk, W. H., and Ward, J. W. (1964). Toxicology and Applied Pharmacology, 6, 340 .

Anand, B. K. (1971). South African Medical fournal, 45, Suppl. No. 12.

Anand, B. K., and Blundell, J. E. (1971). South African Medical fournal, 45, Suppl. No. 53.

Bergmeyer, H. U., and Bernt, E. (1963). In Methods of Enzymatic Analysis, ed. H. U. Bergmeyer, p. 125. Weinheim, Verlag Chemic.

Besser, G. M., Butler, P. W., and Landon, J. (1969). British Medical fournal, 1,528 .

Blackard, W. G., and Heidingsfelder, S. A. (1968). fournal of Clinical Investigation, 47, 1407

Butterfield, W. J. H., and Whichelow, M. J. (1968). Lancet, 2, 109.

Costa, E., Groppetti, A., and Revuelta, A. (1971). British fournal of Pharmacology, 41, 57.

Cryer, P. E., and Daughaday, W. H. (1969). Fournal of Clinical Endocrinology, $29,386$.

Dannenburg, W. N., and Kardian, B. C. (1969). Archives Internationales de Pharmacodynamie, 196, 210.

Duncan, E. H., Regan, N. A., Hyde, C. A., and Sweetman, B. (1965). British fournal of Clinical Practice, 19, 451.

Eddy, R. L., Jones, A. L., Chakmakjian, Z. H., and Silverthorne, M. C. (1971). Fournal of Clinical Endocrinology, 33, 709.

Forhman, L. A. (1972). New England fournal of Medicine, 286, 1391.

Foxwell, M., Funderburk, W. H., and Ward, J. W. (1968). Fournal of Pharmacology, 165, 60 .

Fuxe, K., and Hökfelt, T. (1969). In Neuroendocrinology, ed. W. F. Ganong. and L. Martini, p. 47. London, Oxford University Press.

Hohorst, H., Kreutz, F. H., and Bücher, T. (1959). Biochemische Zeitschrift, 332, 18.
Hunter, W. M. (1969). Excerpta Medica International Congress Series, No 161, p. 5 and part 3, p. 551

Hunter, W. M., Fonseka, C. C., and Passmore, R. (1965). Biochemical fournal, 96,75p.

Hunter, W. M., and Ganguli, P. C. (1971). In Radio-Immuno Assay Methods, ed. K. E. Kirkham and W. M. Hunter, p. 243. Edinburgh, Churchill Livingstone.

Hunter, W. M., and Greenwood, F. C. (1964). British Medical fournal, 1, 804.

Itaya, K., and Ui, M. (1965). Fournal of Lipid Research, 6, 16.

Johnson, R. H., and Rennie, M. J. (1973). Clinical Science, 44, 63.

Kansal, P. C., Buse, J., Talbert, O. R., and Buse, M. G. (1972). Fournal of Clinical Endocrinology and Metabolism, 34, 99.

Lawrence, A. M., Goldfine, I. D., and Kirsteins, L. (1970). Fournal of Clinical Endocrinology and Metabolism, 31, 239.

Le Douarec, J. C., and Schmitt, H. (1964). Therapie, 19, 831.

McCann, S. M. (1970). In The Hypothalamus, ed. L. Martini, M. Molta, and F. Fraschini, p. 277. London, Academic Press.

Morgan, C. R., and Lazarow, A. (1968). Diabetes, 12, 115.

Munro, J. F., Seaton, D. A., and Duncan, L. J. P. (1966). British Medical Fournal, 2,624

Pawan, G. L. S. (1969). Lancet, 1, 498.

Traherne, J. B. (1965). Practitioner, 195, 677.

Williamson, D. H., Mellanby, J., and Krebs, H. A. (1962). Biochemical fournal, 82, 90 .

Wilson, J. P. D., and Galton, D. J. (1971). Hormone and Metabolic Research 3,262 .

Wurtman, R. J. (1970). In Hypophysiotropic Hormones of the Hypothalamus ed. J. Meites, p. 184. Baltimore, Williams and Wilkins.

Ziance, R. J., Sipes, I. G., Kinnard, W. J., and Buckley, J. P. (1972) fournal of Pharmacology, 180, 110.

\title{
Remission of Thyrotoxicosis during Treatment with Propranolol
}

\author{
D. G. MCLARTY, \\ B. E. W. BROWNLIE, \\ W. D. ALEXANDER, \\ P. D. PAPAPETROU, \\ P. HORTON
}

British Medical fournal, 1973, 2, 332-334

\section{Summary}

Twenty-eight thyrotoxic patients were treated with propranolol. In seven patients the drug had to be discontinued after one or two months, but in the remaining 21 clinical improvement was observed. Serial clinical studies and tests of thyroid function performed at monthly intervals showed that in four patients thyrotoxicosis remitted and all indices of thyroid function returned to normal. A fifth patient shows distinct evidence of remission with the 20minute ${ }^{132}$ I uptake falling to normal, although the freethyroxine index remains slightly raised. It is likely that these remissions reflect the natural tendency of the disease to remit since propranolol is not considered to have any direct in-vivo effect on thyroid function.

However, because of failure to gain adequate control of symptoms in all patients treated, and the fact that circulating thyroid hormone levels were often not restored to normal, propranolol is considered an unsatisfactory alternative to conventional antithyroid drugs for routine treatment.

\footnotetext{
University Department of Medicine, Gardiner Institute, Western Infirmary, Glasgow G11 6NT

D. G. McLARTY, M.B., M.R.C.P., Registrar, (Present appointment Lecturer, Department of Materia Medica, Stobhill Hospital Glasgow)

B. E. W. BROWNLIE, M.D., M.R.A.C.P., Research Fellow, (Present appointment: Physician in Charge, Radioisotope Department, Christchurch Hospital, Christchurch, New Zealand)

W. D. ALEXANDER, M.D., F.R.C.P., Reader

P. D. PAPAPETROU, M.D., Research Fellow, (Present appointment Instructor in Medicine, Department of Endocrinology, New England Instructor in Medicine, Department of Endocrinolo

P. HORTON, B.SC., PH.D., Principal Physicist (Present address: Department of Clinical Physics and Bioengineering, West Graham Street, Glasgow)
}

\section{Introduction}

If thyrotoxic patients are given a conventional course of treatment with antithyroid drugs, about $30-50 \%$ experience a prolonged remission and the remainder relapse (Hershman et al., 1966; Alexander et al., 1973). It has usually been thought that antithyroid drugs do not fundamentally affect the course of the disease, but merely inhibit thyroid hormone production until a natural remission occurs. If this is true it would be expected that the rate and frequency of remission of thyrotoxicosis would be independent of the drug used-whether, for example, a patient was treated with carbimazole or propranolol.

In this study remission occurred in several patients treated with propranolol alone in spite of the drug having no direct in-vivo effect on thyroid function (Hadden et al., 1969; Biran and Tal, 1972). Although it has been proposed that propranolol might be suitable as a definitive form of therapy for mild cases of thyrotoxicosis (Pimstone et al., 1969) our evidence suggests that this drug is not an acceptable alternative to conventional antithyroid drug therapy.

\section{Patients and Methods}

Twenty-eight patients were treated with propranolol. Thyrotoxicosis was confirmed by the presence of clinical features of the disease, a free thyroxine index (Clark and Horn, 1965) greater than 8, and in all patients the 20-minute ${ }^{132}$ I uptake (Alexander et al., 1969) was above $8 \%$.

Since effective treatment with standard antithyroid drugs is available we did not think that a strictly controlled clinical trial with random allocation of patients was ethically justifiable. Therefore, patients with severe clinical features 